\title{
First record of the megamouth shark, Megachasma pelagios, (family Megachasmidae) in the tropical western North Atlantic Ocean
}

\author{
Grisel Rodriguez-Ferrer ${ }^{1 *}$ (D, Bradley M. Wetherbee ${ }^{2,5}$, Michelle Schärer $^{3}$, Craig Lilyestrom', Jan P. Zegarra ${ }^{4}$ \\ and Mahmood Shivji ${ }^{5}$
}

\begin{abstract}
Background: A new record of Megachasma pelagios is here reported for the tropical western North Atlantic Ocean from Puerto Rico.

Results: On December 10, 2016, a tourist reported an unusual stranded shark on Mojacasabe Beach, Cabo Rojo, on the southwestern coast of Puerto Rico. Visual examination of the carcass and mitochondrial DNA analysis from a dorsal fin sample revealed it to be a $457 \mathrm{~cm}$ female megamouth shark.

Conclusion: This record represents the first record of M. pelagios for the tropical western North Atlantic Ocean within the Caribbean Sea of southwest Puerto Rico and only the second record of M. pelagios from the North Atlantic.
\end{abstract}

Keywords: Megamouth shark, First record, Puerto Rico, Caribbean, Range extension, DNA barcoding

\section{Background}

The megamouth shark (Megachasma pelagios; Lamniformes: Megachasmidae) was first described based on an individual captured off Hawaii in 1976 (Taylor et al. 1983). The large filter feeding species had a number of unique characteristics and was placed in the new family Megachasmidae and genus. Since description of the holotype, the occurrence of at least 65 confirmed specimens with locations has been reported (FLMNH 2017). The International Union for Conservation of Nature (IUCN) Red List reports 102 specimens, but all of the specific locations are not provided (Simpfendorfer and Compagno 2015). The vast majority of confirmed reports are from the Indo-Pacific (FLMNH 2017). Only three have been reported from the Atlantic Ocean, two from Brazil and one from Senegal (Seret 1995, Amorim et al. 2000). Since many megamouth shark records are from fisheries interactions, further research on its

\footnotetext{
*Correspondence: grodriguezf@drna.gov.pr

${ }^{1}$ Department of Natural and Environmental Resources, Recreational and Sport

Fisheries Division, PO Box 366147, San Juan 00936, Puerto Rico

Full list of author information is available at the end of the article

ecology and habitat use is needed to better understand this species, currently listed as Least Concern by the IUCN (Simpfendorfer and Compagno 2015). On December 2016, a large shark carcass was reported on the southwestern coast of Puerto Rico. Details concerning the identification of a megamouth shark, Megachasma pelagios, are presented.

\section{Methods}

On December 10, 2016, a tourist reported a stranded shark on Mojacasabe Beach, Cabo Rojo (17.980570 N, $-67.210663 \mathrm{~W})$, on the southwestern coast of Puerto Rico. Rodríguez-Ferrer verified the finding and confirmed the shark was dead and in an advanced stage of decomposition. Images of the specimen and total length were recorded and a dorsal fin sample was collected and frozen for DNA analysis. Sample was sent to and analyzed at the Nova Southeastern University, Halmos College of Natural Sciences and Oceanography.

Genomic DNA was extracted from $\sim 25 \mathrm{mg}$ of dorsal fin tissue using the QIAGEN DNeasy kit (QIAGEN Inc., Valencia, CA, USA). An approximate 655-base pair (bp) 
fragment from the 5 ' region of the mitochondrial cytochrome c oxidase 1 gene (COI) was polymerase chain reaction (PCR) amplified using a cocktail of the primer sets FishF1 (5'-TCAACCAACCACAAAGACATTGGCAC-3'), FishF2 (5'-TCGACTAATCATAAAGATATCGGCAC-3'), FishR1 (5'-TAGACTTCTGGGTGGCCAAAGAATCA-3'), and FishR2 (5'-ACTTCAGGGTGACCGAAGAATCAGA A- 3') (Ward et al. 2005), and following procedures in Wong et al. (2009). The entire ( 1300-bp) of the mitochondrial control region was PCR amplified using primers and procedures in Clarke et al. (2015). Amplicon purification and sequencing for both mitochondrial regions followed Clarke et al. (2015), with the exception that the amplicons were sequenced in one direction only using the FishR1 primer for COI and forward primer for control region. Species identity was checked by querying the National Center for Biotechnology Information (https://www.ncbi.nlm.nih.gov/) and Barcode of Life (http://www.boldsystems.org/) databases. Sequence divergence between our megamouth specimen and one sampled from the western Pacific (Chang et al. 2014 ) at the COI and control region was estimated in MEGA 7 (Kumar et al. 2017) as uncorrected $p$-distance (expressed as percent difference between the two sequences).

\section{Results}

\section{Systematic account}

Family: Megachasmidae Taylor et al. 1983

Genus: Megachasma Taylor et al. 1983

Megachasma pelagios Taylor et al. 1983

Common name: Megamouth shark

\section{Description}

The shark carcass was in an advanced stage of decomposition. Water depth where the shark was recovered was $0.9 \mathrm{~m}$. The shark carcass presented a "tadpole" body shape, large head, prominent mouth with large fleshy lips, many small triangular shaped teeth, five gill slits, brown coloration, flabby body and long upper caudal lobe that were consistent with descriptions in previous reports of $M$. pelagios specimens (Taylor et al. 1983, Nakaya et al. 1997). The specimen was a female measuring $457 \mathrm{~cm}$ in total length (TL). Fishing gear, scars or injuries were not observed on the body of the shark and no obvious cause of death was evident by visual inspection. Several photographs were taken for evidence (Fig. 1). After the examination and given the shark's advanced state of decomposition, the carcass was towed out to sea and discarded with the help of local commercial anglers.

\section{Genetics}

A tissue sample was taken from the dorsal fin for DNA analysis. Both COI (622 bp) and control region (613 bp) sequences confirmed the specimen as $M$. pelagios (GenBank accession numbers KY392958 and KY379851, respectively). Sequence divergence ( $p$-distance) between the Puerto Rico specimen and the Pacific specimen was $0.0 \%$ for COI and $0.32 \%$ for the control region.
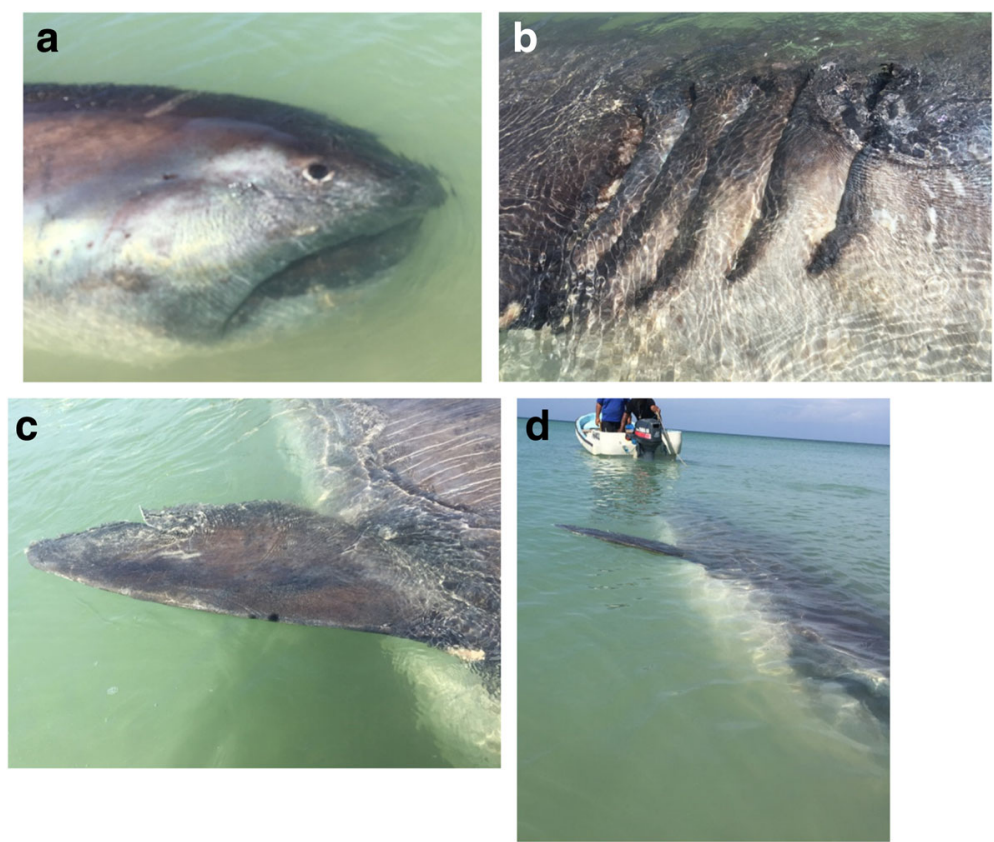

Fig. 1 Megamouth shark carcass photos taken in Cabo Rojo, Puerto Rico (December 2016), female, $457 \mathrm{~cm}$ TL (a lateral view of the head, b gill slits, c right pectoral fin, $\mathbf{d}$ carcass being towed) 


\section{Discussion}

The finding of a megamouth shark in Puerto Rico expands the distribution for this species. This is only the second report of the species from the North Atlantic Ocean and the first report from the tropical western North Atlantic Ocean or Caribbean Sea. It is possible that megamouth sharks are more common in the Pacific Ocean, but the species has a wider distribution that now includes all sides of the Atlantic Ocean as well as an additional low-latitude record.

Of the three instances where megamouth sharks were observed in the Atlantic Ocean, two were males and one was of undetermined sex; therefore, this is the first confirmation of a female megamouth in the western hemisphere. Given the estimated size at maturity for females at $5 \mathrm{~m}$ (Nakaya et al. 1997, Smale et al. 2002, Nakaya 2008) this specimen was likely immature or a sub-adult, although the reproductive tract was not examined. No mating scars were observed on the body as reported in a larger, sexually mature female captured in Japan (Yano et al. 1997). It has been suggested that juvenile and adult megamouth sharks segregate geographically, with juveniles more common in lower latitudes, expanding their range to higher latitudes as they age (Nakaya 2008). Some records suggest year-round presence at higher latitudes and possible migration to lower latitudes during part of the year (Nakaya 2008). The three previous records from the Atlantic Ocean were in May in Senegal (Seret 1995) and September and July in Brazil (Amorim et al. 2000, Lima et al. 2009). These records, plus the present specimen stranded in December in Puerto Rico are consistent with geographical segregation by size and suggest that the species is present in the Atlantic year round, including at lower latitudes.

Based on the morphology and stomach contents of other megamouth sharks (Taylor et al. 1983, Nakaya et al. 2008, Sawamoto and Matsumoto 2012) as well as distinct daily vertical movements demonstrated by a megamouth shark tracked using acoustic telemetry (Nelson et al. 1997), these sharks are filter feeders that prey on plankton. Lower productivity of low latitude waters compared to higher latitudes may partly explain the paucity of reports of megamouth sharks at low latitudes such as the Caribbean Sea, and why the majority of records are from more temperate waters.

The $p$-distances provide the first estimate of mitochondrial DNA sequence divergence between Atlantic and Pacific megamouth sharks. The absence of nucleotide polymorphisms $(p$-distance $=0.0 \%)$ in the COI barcode and only two variable sites in the control region ( $p$-distance $=0.32 \%)$ between widely separated individuals from different ocean basins may portend low global matrilineal genetic diversity in this enigmatic species, as seen in another pelagic filter-feeding lamniform, the basking shark (Hoelzel et al. 2006). However, confirmation of this low diversity will require further investigation with larger sample sizes.

\section{Conclusion}

The importance of the present record resides in the fact that it represents the first record of $M$. pelagios for Puerto Rico and a significant range extension into the tropical western North Atlantic Ocean.

\section{Abbreviations \\ bp: Base pairs; cm: Centimeter; COI: Cytochrome c oxidase 1 gene; DNER: Department of Natural and Environmental Resources; FLMNH: Florida Museum of Natural History; PCR: Polymerase chain reaction; TL: Total length}

\section{Acknowledgments}

We thank K. Finnegan for conducting the laboratory genetics analysis, the local commercial anglers who towed the shark carcass offshore, and Sgt. H. Ronda and DNER Rangers Mr. Vargas and Mr. Lugo for their support during the finding. We are grateful to the anonymous reviewer whose suggestions improved the manuscript.

\section{Funding}

The DNA analysis laboratory work was supported by funding from the Guy Harvey Ocean Foundation and Save Our Seas Foundation.

\section{Availability of data and materials}

Another piece of fin sample is available at the DNER Fisheries Laboratory in Puerto Rico. Photographs and data supporting the conclusions of this article are included.

\section{Authors' contributions}

GR visually examined the carcass, took fin sample and photographs, revised literature and completed the first draft of this manuscript. BMW and MSh completed all the genetic analysis and discussion. MSc and CL provided additional references and information on the species. MSh provided the funding source. JPZ provided initial shark identification and prepared manuscript for submittal. All authors contributed edits and comments to the draft manuscript and read and approved the final manuscript.

\section{Competing interests}

The authors declare that they have no competing interests. The findings and conclusions in this article are those of the author(s) and do not necessarily represent the views of the U.S. Fish and Wildlife Service.

Consent for publication

Not applicable.

Ethics approval and consent to participate Not applicable.

\section{Publisher's Note}

Springer Nature remains neutral with regard to jurisdictional claims in published maps and institutional affiliations.

\section{Author details}

${ }^{1}$ Department of Natural and Environmental Resources, Recreational and Sport Fisheries Division, PO Box 366147, San Juan 00936, Puerto Rico. ${ }^{2}$ Department of Biological Sciences, University of Rhode Island Kingston, 120 Flagg Road, Kingston, RI 02881, USA. 'H.J.R Reefscaping, P. O. Box 1442, Boquerón 00622 Puerto Rico. ${ }^{4}$ U.S. Fish \& Wildlife Service, Caribbean Ecological Services Field Office, P. O. Box 491, Boquerón 00622, Puerto Rico. ${ }^{5}$ Guy Harvey Research Institute and Save Our Seas Shark Research Center, Nova Southeastern University, 800 N Ocean Drive, Dania Beach, FL 33004, USA. 
Received: 3 February 2017 Accepted: 28 April 2017

Published online: 29 June 2017

\section{References}

Amorim AF, Arfeli CA, Castro Jl. Description of a juvenile megamouth shark, Megachasma pelagios, caught off Brazil. Environ Biol Fishes. 2000;59:117-23.

Chang CH, Shao KT, Lin YS, Chiang WC, Jang-Liaw NH. Complete mitochondrial genome of the megamouth shark Megachasma pelagios (Chondrichthyes, Megachasmidae). Mitochondrial DNA. 2014;25:185-7.

Clarke CR, Karl SA, Horn RL, Bernard AM, Lea JS, Hazin FH, Prodöhl PA, Shivji MS. Global mitochondrial DNA phylogeography and population structure of the silky shark, Carcharhinus falciformis. Mar Biol. 2015;162:945-55.

Florida Museum of Natural History. Confirmed Megamouth Shark Sightings. 2017. https://www.flmnh.ufl.edu/fish/sharks/megamouth/MegaMap.htm. Accessed 15 Jan 2017.

Hoelzel RA, Shivji MS, Magnussen JE, Francis MP. Low worldwide genetic diversity in the basking shark (Cetorhinus maximus). Biol Lett. 2006;2:639-42.

Kumar S, Stecher G, Tamura K. MEGA7: Molecular Evolutionary Genetics Analysis version 7.0. 2017. http://www.megasoftware.net/docs

Lima LM, Rennó B., Siciliano S. Gigante dos mares em areias fluminenses. Um dos mais raros tubarões do mundo é encontrado na costa brasileira. Ciência Hoje 2009; Ed 263.

Nakaya K. Biology of the megamouth shark. Megachasma pelagios (Lamniformes: Megachasmidae) Zool. 2008;52:603-7.

Nakaya K, Yano K, Takada K, Hiruda H. Morphology of the first female megamouth shark, Megachasma pelagios (Elasmobranchii: Megachasmidae), landed at Fukuoka, Japan. In: Yano K, Morrissey J, Yabumoto Y, Nakaya K, editors. Biology of the megamouth shark. Tokyo: Tokai Univ. Press; 1997. p. 51-62.

Nakaya K, Matsumoto R, Suda K. Feeding strategy of the megamouth shark Megachasma pelagios (Lamniformes: Megachasmidae). J Fish Biol. 2008;73: 17-34.

Nelson DR, McKibben JN, Strong Jr WR, Lowe CG, Sisneros JA, Schroeder DM, Lavenberg RJ. An acoustic tracking of a megamouth shark, Megachasma pelagios: a crepuscular vertical migrator. Environ Biol of Fish. 1997:49:389-99.

Sawamoto S, Matsumoto R. Stomach contents of a megamouth shark Megachasma pelagios from the Kuroshio Extension: evidence for feeding on a euphausiid swarm. Plankton Benthos Res. 2012;7:203-6.

Seret B. Premiere capture d'un requin grande gueule (Chondrichthyes, Megachasmidae) dans l'Atlantique, au large du Senegal. Cybium. 1995;19:425-7.

Simpfendorfer C, Compagno LJV. Megachasma pelagios. The IUCN Red List of Threatened Species 2015: e.T39338A2900476. http://dx.doi.org/10.2305/IUCN. UK.2015-4.RLTS.T39338A2900476.en. Accessed 15 Jan 2017.

Smale MJ, Compagno LJV, Human BA. First megamouth shark from the western Indian Ocean and South Africa. S Afr J Sci. 2002;98(7-8):349-50.

Taylor LR, Compagno LJV, Struhsaker PJ. Megamouth- a new species, genus, and family of lamnoid shark (Megachasma pelagios, family Megachasmidae) from the Hawaiian Islands. Proc Calif Acad Sci. 1983;43(8):87-110.

Ward RD, Zemlak TS, Innes BH, Last PR, Herbert PDN. DNA barcoding Australia's fish species. Phil Trans R Soc B. 2005;360:1847-57.

Wong EHK, Shivji MS, Hanner RH. Identifying sharks with DNA barcodes: assessing the utility of a nucleotide diagnostic approach. Mol Ecol Resour. 2009:9:243-56

Yano K, Yoshitaka Y, Sho T, Osamu T, Masami F. Capture of a Mature Female Megamouth Shark Megachasma pelagios, from Mie, Japan. Proceedings of the 5th Indo-Pacific Fish Conference. 1997:335-49.

\section{Submit your next manuscript to BioMed Central and we will help you at every step:}

- We accept pre-submission inquiries

- Our selector tool helps you to find the most relevant journal

- We provide round the clock customer support

- Convenient online submission

- Thorough peer review

- Inclusion in PubMed and all major indexing services

- Maximum visibility for your research

Submit your manuscript at www.biomedcentral.com/submit
) Biomed Central 